\title{
THE LEGAL AND POLITICAL ASPECTS OF POPULATION CONTROL IN THE UNITED STATES
}

\author{
Alvat W. Sulloway*
}

Although it might be convenient to discuss the legal and political aspects of population control in the United States as if they were two separate topics, any such arbitrary division of the subject could well obscure the close relationship between them. Unfortunately, the word "political" is one of the debased coins of our language. Once encompassing the whole range of man's activities in relation to the common good, the sense of this adjective is now limited to the art of obtaining and retaining public office. If we go back to the older sense of the word, however, we can observe a truly "political" aspect in the history of the legislation against contraceptives in the United States in the attitudes of lawmakers and judges toward attempted changes in these laws and in the current controversies, of far-reaching importance in their impact upon personal freedom, over the availability of contraceptive advice in publicly-supported hospital and welfare services and in the foreign-aid programs of our own Government. The subject cuts across vistas of human lifenot merely legal, but religious and social; not merely theoretical, but practical and immediate.

Interestingly enough, some measures of population control have run afoul of the law, while others have escaped any such proscriptive legislation. In the latter category are ( $\mathrm{r}$ ) absolute continence, a time-honored method of family limitation formerly, but no longer, extolled by the Roman Catholic Church as the only permissible alternative to contraception; (2) periodic continence, sometimes called rhythm, a method now approved and even under some circumstances recommended by the Roman Catholic hierarchy; (3) coitus interruptus, ${ }^{1}$ perhaps the most widely practiced of all birth control measures; and (4) coitus reservatus, ${ }^{2}$ a more exacting technique requiring an even greater degree of self-control than coitus interruptus. All of these have the virtue of being both legally permissible and inexpensive. One of them, absolute continence, possesses the added advantage of being foolproof. The other available methods, sterilization, abortion, and contraception, are still entangled in a maze of legislative prohibition or regulation. It is these three last-named methods that will be the subject of more detailed discussion in this article.

- A.B. I938, LL.B. I941, Harvard University. Member of the Connecticut and New Hampshire bars. Formerly Chief Secretariat, Office of Strategic Services. Author, Birth Control and Carmolic DocTRINE (1959).

${ }^{1}$ Condemned by the Roman Catholic Church by reason of its analogy to the sin of Onan in Genesis 38:9.

Permitted by the Roman Catholic Church because, unlike coitus interruptus, its essence is the avoidance of ejaculation. See Marie C. Stopes, Rosas Catholic Methods of Birth Contror 22, 46, $52,52,6$ I (1933). 


\section{Sterilization}

Sterilization in the United States has never been regarded as a measure of population control, although it eminently qualifies as such and is currently being used for this purpose in such countries as Japan, Puerto Rico, and India." Sterilization involves an operation upon the reproductive organs of a man or woman with a view to terminating permanently his or her capacity to produce a child. The most common male operation, known as vasectomy, cuts and seals a part of the tube through which the sperm proceeds from the testicle to the urethra. Salpingectomy, in the case of a woman, involves the severing or tying of the fallopian tubes, through which the ovum passes from the ovary into the womb. Neither of these operations entails any loss or sacrifice of sexual pleasure. Both are drastic in that the sterility thereby achieved is permanent, with no assurance that the result can be reversed by a subsequent operation."

Legally, sterilization is required in many states ostensibly for eugenic reasons, and to this extent, it may be considered a form of population control, although on a strictly limited scale. The laws of twenty-eight states requiring sterilization in certain cases are aimed for the most part at idiots, the feeble-minded, imbeciles, and insane persons, and in all but six of these states, epileptics. 5 The presumption, of dubious validity in the case of many mental ailments, that such defects are hereditary suggests that some of these statutes may also have a punitive purpose-and if not a punitive purpose, at least a punitive effect. In two of the states, sterilization may be performed only with the consent of the person involved or his guardian; in actual practice, however, consent is usually obtained in many other states as well, despite the legal authority to proceed without it. ${ }^{\circ}$ Most of the sterilization statutes apply only to persons confined in state mental institutions, but in eight states having such laws, sterilization may be required of persons outside of state mental institutions. $^{7}$

Two other classes of people falling within the purview of sterilization statutes in some states are "habitual" criminals and sex offenders or perverts. ${ }^{8}$ These statutes rest upon a shakier foundation than the ones applicable only to mental defectives,

${ }^{3}$ For Japan, see Mary Steichen Calderone (ED.), Abortion in the United States 201 (1958); News of Population and Birth Control, Jan. 1960, p. 2; Bronfenbrenner \& Buttrick, Population Control in Japan: Economic Theory and Its Application, supra pp. 536, 555. For Puerto Rico, sce Stycos \& Hill, The Prospects of Birth Control in Puerto Rico, 285 ANnals 137, 139-40 (1953); Back, Hill \& Stycos, Population Control in Puerto Rico: The Formal and Informal Framework, supra pp. 558, 571-73. For India, see N.Y. Times, March 7, 1960, p. II, col. I; Agarwala, Population Control in India: Progress and Prospects, supra pp. $577,592$.

- Granville Williams, The Sanctity of Life and the Criminal LaW 75 (ig57). See also O'Connor, Anastomosis of Vas Differens After Purposeful Division for Sterility, 136 A.M.A.J. I62 (1948), which indicates that the vasectomy procedure may be successfully reversed in 35 to $40 \%$ of the cases where it has been undertaken. New techniques may increase this percentage. Sce 78 SciEnce N.L. 5 (1960).

'Sec Harriet F. Pilpel \& Theodora Zavin, Your Marriage and the LAw 200 et seq. (1952).

'Id. at 203-04.

Td. at 205 .

Id. at 206-07. 
for there is even less evidence of the inheritability of criminal tendencies and of a predisposition to sex offenses. Since vasectomy does not eliminate the desire for sex, it presumably is not effective in altering the conduct of a man who repeatedly violates the law by assaulting young girls. On the other hand, castration, while doubtless more effective in this regard, involves an extreme degree of mutilation, putting it beyond what most civilized people consider to be the reasonable limits of interference with human life and dignity. ${ }^{9}$

These compulsory sterilization statutes have had only a minor eugenic impact upon the population of the United States. As of 1952, it was estimated that a total of 52,000 people had been sterilized under these statutes, a relatively small percentage of the defective members of our population..$^{10}$ In view of the growing recognition of our lack of knowledge as to what defects are inheritable as opposed to having environmental origins, and in view of the failure of most such laws to include defectives who are not inmates of state mental institutions, it seems unlikely that our existing sterilization laws will play much of a role in preventing the eugenic deterioration of our population.

The present status, both legal and medical, of sterilization statutes is doubtful. The only United States Supreme Court case upholding such a statute (Virginia) was decided in 1927 on limited facts involving a female feeble-minded person. ${ }^{11}$ In this case at least, some evidence as to the transmittability of mental defectiveness was before the Court. Fifteen years later, the United States Supreme Court struck down an Oklahoma statute providing for sterilization of an "habitual criminal,"12 and the questions plainly in the minds of the justices, although not specifically before the Court, may well prove fatal to other such statutes if their constitutionality is ever tested. As Mr. Justice Douglas, speaking for the Court, said: ${ }^{13}$

The power to sterilize, if exercised, may have subtle, far-reaching and devastating effects. In evil or reckless hands it can cause races or types which are inimical to the dominant group to wither and disappear. There is no redemption for the individual whom the law touches.

Mr. Chief Justice Stone, concurring in the result, expressed the opinion that a violation of the due process rather than the equal protection of the laws clause of the United States Constitution compelled the decision reached by the Court. In this case, the Chief Justice observed, the individual had no opportunity to show that he

\footnotetext{
${ }^{\circ}$ Wrlliams, op. cit. supra note 4, at 91; Pilpel \& Zavin, op. cit. supra note 5, at 208 . The current Nebraska statute, Neb. Rev. Stat. 83-501-08 (Supp, 1957), does not specifically use the term "castration," authorizing "sterilization," a broader term. The statute is, nevertheless, indexed under the subheading "castration." It provides that "such an operation be performed for the prevention of procreation as in the judgment of the Board of Examiners would be most appropriate to each individual case." E. S. Gosney \& Paul Popenoe, Sterizization for Human Betterment 168 (1929), describes Delaware and Oregon as two states where castration has predominated.

${ }^{10}$ PILPEL \& ZAviN, op. cit. supra note 5, at 205; WILliAMs, op. cit. supra note 4 , at 83 .

11 Buck v. Bell, 274 U.S. 200 (1927).

19 Skinner v. Oklahoma, 316 U.S. 535 (1942).

${ }^{13} I d$. at $54 \mathrm{x}$; see also the concurring opinion of Mr. Justice Jackson. Id. at 546 .
} 
did not possess inheritable tendencies, the existence of which was presupposed by the Oklahoma statute. ${ }^{14}$ Recent medical knowledge, moreover, has tended to weaken the scientific basis for the sterilization statutes and to envelop the subject in an ever-widening mantle of genetic uncertainties. ${ }^{15}$

A more difficult question arises as to the availability of sterilization procedures to persons seeking them voluntarily for therapeutic reasons. The statutes of nine states appear to permit sterilization where medical or surgical treatment has incidentally destroyed a patient's reproductive capacities. ${ }^{16}$ By implication in such states, sterilization would seem to be unlawful if directly undertaken even for therapeutic reasons, but it is doubtful whether this was the intent of the legislature and whether the statutes would be so construed. A more liberal construction of such statutes would be consistent with the laws of Connecticut and Kansas, which expressly prohibit sterilization except in cases of "medical necessity,"17 and with the law of New Hampshire, which permits it for "sound therapeutic reasons." ${ }^{8}$ In the absence of a statute, the common-law rule would appear to permit such operations. ${ }^{10}$

Sterilization exclusively as a birth-control measure often poses grave practical problems as well as serious unresolved legal questions. It has previously been noted that some states permit sterilization for therapeutic reasons. A voluntary request for sterilization in these states without medical indications would, therefore, seem to be unauthorized and hence illegal under the laws of these states. Furthermore, regardless of law, the medical profession is generally loath to perform such operations, and some hospitals require certification by several physicians as to medical necessity. ${ }^{20}$ Roman Catholic doctors and hospitals uniformly refuse to perform sterilization operations on religious grounds, and such operations are expressly prohibited by the Catholic Hospital Code of Ethics. ${ }^{21}$ Curiously, the legality of a sterilization operation in the absence of any statutory prohibition is unsettled. The question boils down to whether a patient can lawfully consent to the operation, or whether there is something so drastic and maiming about it that even the patient's consent can not cure the inherent evil of the procedure. ${ }^{22}$ Doubt as to how a court will answer this question, coupled with a lack of judicial authority, undoubtedly contributes to the reluctance of the medical profession to make voluntary sterilization a more readily available birth-control measure in the United States.

14 Id. at $543-45$.

${ }^{26}$ See the concurring opinion of Mr. Justice Jackson, id. at 546; see aslo Myerson, Certain Medical and Legal Phases of Eugenic Sterilization, 52 YALE L. J. $6 \mathrm{r8}$ (1943); Cook, Eugenics or Euthenics, 37 ILL. L. Rev. 287 ( 1943 ).

${ }^{10}$ Pilpel \& Zavin, op. cit. stipra note 5, at 209.

${ }^{12}$ Conn. Gen. Stat. Rev. $\$ 53-33$ (I958); Kan. Gen. Stat. Anv. $\$$ 76-155 (1949).

${ }^{28}$ N.H. REv. STAT. ANN. \$ 74:12 (I955).

${ }^{10}$ See discussion in PilPel \& Zavin, op. cit. supra note 5, at 208-10; Williams, op. cit. supra note 4 , at 77, 102-09.

${ }^{20}$ Pilpel \& Znvin, op. cit. supra note 5, at $2 \mathrm{rI}$; Williams, op. cit. supra note 4 , at 97 .

${ }^{21}$ See Edwin F. Healy, Medical Ethics (1956), for a verbatim text of this Code.

22 Williams, op. cit. stpra note 4, at 102 et seq. 
Abortion

Unlike sterilization, abortion in the United States is conceded to be a major, if nonetheless undesirable, form of population control. There are no reliable estimates on the annual number of abortions in this country. Figures range all the way from Dr. Fred J. Taussig's estimate for 1935 of $700,000,{ }^{23}$ P. K. Whelpton's estimate for 1940 of between 318,000 and $415,000,{ }^{24}$ and an estimate in 1955 at the Planned Parenthood Federation Conference on Abortion of 200,000 as a possible low and $\mathrm{I}, 200,000$ as a possible high, with the further qualification that "there is no objective basis for the selection of a particular figure between these two estimates." ${ }^{25}$ Contrary to popular belief, most abortions are performed on married women; in fact, a substantial number of operations are even carried out where no pregnancy exists. ${ }^{26}$

Abortion is a crime prohibited everywhere throughout the United States. ${ }^{27}$ The statutes of most states contain an express exception permitting an abortion for therapeutic reasons-i.e., to preserve the life of the mother, and in two instances also her health. Six states permit abortion to save the life of an unborn child. Two states enlarge the exception to include the prevention of serious or permanent bodily injury. Where the statutes do not expressly except therapeutic reasons, the courts have read such an exception into the statute by judicial construction. Often certification by two physicians is required as evidence of therapeutic necessity. Generally the burden of proof is on the state to show its absence. ${ }^{28}$

The application of these statutes presents numerous problems of interpretation. ${ }^{29}$ Do they apply only when the woman is pregnant or also when she thinks she is pregnant but is not? What about an abortion committed by a mother on herself? In New York, as in England, she can be held guilty of a crime. If she merely consents to the abortion but does not induce it herself, she may be guilty as an accomplice in some states and go scot-free in others. For how long must a woman be pregnant before she can have a criminal abortion? Although the theologians have finally concluded that a human soul comes into existence at the moment of conception, legislators and judges in a few states are less imaginative, holding that no criminal abortion can take place unless the child has "quickened" in its mother's womb, an event occurring four to five months after conception, or that a different

${ }^{23} I d$, at 209.

26 Nat'l Comm. on Maternal Health, The Abortion Problem 15, 23 (1944). Three hundred and fifty thousand abortions per year would amount to 13.7 abortions per every too live births.

${ }^{25}$ CaldoRone, op. cit. supra note 3 , at 180 .

20. PILPEL \& Zavin, op. cit. supro note 5 , at $184-85$.

${ }^{27}$ For an excellent summary analysis of abortion laws in the United States, see Harper, Abortion Laws in the United States, in Calderone, op. cit. supra note 3, app. A, at 187 .

${ }^{28}$ Calderone, op. cit. supra note 3 , at $187-88$.

${ }^{20}$ See Willians, op. cit. supra note 4 , at 157 et seq., for a discussion of the questions herein set forth, with citation of statutes and cases. 
penalty will apply. ${ }^{30}$ If the statute does not refer to quickening, as is the case in most states, the penalty follows whether there is quickening or not. Must the woman feel it and recognize the movement as belonging to an unborn foetus? In some states, evidence of her knowledge is essential. What if the foetus is dead? A number of states have construed their statutes to prohibit its removal under these circumstances on the theory that such a rule deprives the illicit abortionist of a defense, difficult to rebut, that the foetus was already dead when he operated.

No purpose would be served in reviewing here all of the shades of judicial interpretation arising under the abortion statutes. Therapeutic abortion, unlike abortion for other reasons, is primarily a medical problem rather than a measure of population control. Glanville Williams, in his admirably written The Sanctity of Life and the Criminal Law, provides a competent survey of the existing authorities on the subject of therapeutic abortion, and the interested reader is referred to his work for further details. ${ }^{31}$ From the standpoint of population control, we may say that although the abortion statutes make abortion for this or any other purpose except medical necessity a crime, these statutes have no deterrent effect in most cases. Once an unwanted pregnancy occurs, abortion is the only alternative open to the mother who does not want to give birth to a child. The number of therapeutic abortions legally performed by the medical profession is thus a tiny fraction of the total number of estimated abortions per year, so that notwithstanding the law, abortion continues to be a widely-used measure of family limitation in the United States.

\section{III}

\section{CONTRACEPTION}

Of the three population-control techniques that are subject to legal regulations in the United States, contraception is the one whose limitation is most difficult to justify on any rational ground. Compulsory sterilization, for example, patently involves a serious interference with the physical integrity of the human body and with an important human freedom, the right to procreate new life. In the absence of consent, it would incontrovertibly constitute an unlawful touching or battery, unless authorized by the legislature. Abortion not only interrupts the growth of the embryo, but causes its premature destruction, an act analogous to homicide in the case of a live human being. In both instances, public policy may well have an interest in preventing operations, even though voluntarily undertaken, that destroy the reproductive capacity or an incipient life after conception and that also expose the patient to major physical changes or hazards. Recommended contraceptive techniques, on the other hand, do not cause permanent physical changes in the human body; they entail no risks to life or health. ${ }^{32}$ Indeed, legislative prohibitions against

\footnotetext{
${ }^{30}$ See also Pilpex \& ZAvin, op. cit. supra note 5, at $19 \mathrm{r}$.

$: 1$ Williams, op. cit. supra note 4 , at $\mathrm{r} 60$ et seg.

a2 Norisan E. Himes \& Abraham Stone, Planned Parenthood 6r, 63 et seq., 78-80 (195I).
} 
them seem to have arisen out of the rather dubious assumption that because they are intimately concerned with human reproduction, they are properly classifiable with other less controversial, forbidden forms of immorality.

Contraception crept into the law as it has into modern life--by the back door, concealed within the framework of legislation primarily devoted to other purposes. Statutory provisions against contraceptives constitute a very minor part of a large body of laws devoted to obscene literature, abortion, unnatural vice, and other perversions. For instance, "Crimes Against Chastity, Morality, Decency and Good Order" is the general title of those sections of the Massachusetts laws dealing with contraceptives. ${ }^{33}$ Also classified under this title are adultery, polygamy, incest, fornication, abortion, sodomy, buggery, keeping a house of ill fame, and detaining a woman therein. An attorney going to the digests for cases on birth control will likewise look in vain for any such primary classification as "Birth Control." In the West Publishing Company digests, birth control cases are listed under such headings as Abortion, Obscenity, Statutes, Constitutional Law, and Post Office.

The development of the law of obscenity constitutes a relatively recent chapter in the history of our legal system, furnishing little precedent for the type of prosecution contemplated by English Obscene Publications Act of $1857^{34}$ or by the American obscenity statutes that followed about sixteen years later. Early convictions for obscene conduct or utterances at common law usually entailed some other punishable offense such as blasphemy, sedition, or breach of the peace in private revenge, and the existence of the crime of obscenity per se, eloquently questioned by some of the great judicial minds of the eighteenth century, seems for all practical purposes to be of comparatively recent innovation..$^{35}$ Only with Lord Cockburn's judgment in $x 868$ in Regina v. Hicklin ${ }^{36}$ did there appear a new test of obscenity based upon a tendency to deprave and corrupt "those whose minds are open to such immoral influences." A few years later, American judges, faced with the interpretation of the so-called Comstock laws passed at the behest of a fanatical crusader against pornography named Anthony Comstock, seized upon Lord Cockburn's test to define the meaning of such words as "lewd," "lascivious," "indecent," and "obscene."

The original federal law, upon which many state statutes were modeled, closed the United States mails to various types of obscene literature and articles, including contraceptives. $^{37}$ Another section of the law sealed off the United States Customs from the importation of such information and articles..$^{38}$ Also through its regula-

${ }^{33}$ 9A MAss. ANN. LAws ch. 272, $\$ 20,21$ (1956).

${ }^{34} 20$ \& 2 I Vict., c. $83, \S \mathrm{x}$.

${ }^{35}$ See Alvah W. Sulloway, Birth Control and Catholic Doctrine to et seq. (1959), and notes beginning at 176 , which cite and quote extensively from the English cases.

${ }^{30}$ L. R. 3 Q.B. 360,37 ( 1868 ).

${ }^{37}$ See $\$ 2$ of the bill as originally enacted, I7 Stat. 598 ( 1873 ); CoNg. Grobe, $42 d$ Cong., 3d Sess., pt. 3 , at 2005 ( 1873 ). The modern version of this section may be found in 72 Stat. 962 , 18 U.S.C. $\$ 1461$ (1958).

${ }_{33} \$ 3$, x7 Stat. 598 ( 1873 ), the modern version of which may be found in 62 Stat. 862 ( 1948 ), xg U.S.C. $\$ 1305$ (a) $(1958)$. 
tion of interstate commerce, Congress made common carriers subject to a similar prohibition. ${ }^{39}$

It is interesting to speculate on the reasons for the choice of the law of obscenity as the principal vehicle for the legislation against contraceptives. The only apparent connection between contraceptives and obscenity was provided by the common denominator of their relationship to sex and by their association with "obscene and immoral rubber articles," some of which Comstock himself described as intended "for masturbation." None of the discussion recorded in the Congressional Globe prior to the enactment of the federal law suggests any express legislative intent with respect to contraceptives as such. All we know is that an exemption of the medical profession contained in an early draft of the bill was later omitted apparently, if for any reason at all, in the thought that it was unnecessary. ${ }^{41}$

Had Comstock, Congress, and the many states that modeled their laws on the original federal act been motivated by a fear of underpopulation or race suicide rather than by a horror of indecency, the English common law provided a more appropriate precedent than the law of obscenity-i.e., the so-called crime of depopulationfor regulating the distribution of contraceptives. In the sixteenth century, punitive measures could be and were, in fact, taken to prevent depopulation, particularly against enclosers who, by fencing the arable fields and transforming them into pasture, stripped the countryside of its farms. ${ }^{42}$ Depopulation remained a continuing problem in Europe until the end of the eighteenth century, as witness the plans of Robespierre and other revolutionary leaders for the systematic depopulation of France. ${ }^{43}$ But there is no indication of any concern over depopulation or race suicide in the minds of the legislators who enacted the Comstock laws. On the contrary, the inclusion of contraceptives in such laws seems to have been solely attributable to the Victorian shotgun approach to obscenity.

The passage of the federal law in 1873 touched off a frenzy of legislative activity throughout the states. ${ }^{44}$ Every state except New Mexico passed an obscenity law that could be construed to restrict the distribution of contraceptives, even though contraceptives were not mentioned. More than half of the states specifically included contraceptives. As a result of this legislative action, the United States acquired a unique distinction. In no other country of the world had contraceptive information per se thus been classified with penalized indecency.

Our current statutory legacy from the Comstock laws makes an interesting commentary on the gap between moral theory and practice. Thirty-one states now pro-

${ }^{30} 29$ Stat. 512 ( 1897 ), the modern version of which may be found in 72 Stat. 962 , 18 U.S.C. $\$ 1462$ (1958).

${ }^{10}$ Cong. Globe, $42 \mathrm{~d}$ Cong., 3d Sess., pt. 3, app. 168 ( 1873 ).

${ }^{11} I d$. pt. 2, at 1436 , 1525 . The effect of this omission was discussed in United States r. One Package, 86 F.2d 737, 740 (2d Cir. 1936), and considered to be of no significance by Judge Augustus N. Hand, who wrote the court's opinion, although Judge Learned Hand, in a concurring opinion, disagrees.

${ }_{4}{ }_{4}$ William Holdsworth, History of English LAW 366 (ig26).

${ }^{43}$ Nesta H. Webster, World Revolution 44 et seq., 63 (I921).

14 Mary Ware Dennett, Birth Control Laws 28 (1926); Notes, 45 Harv. L. Rev. 723 (1932), 6 U. CHI. L. Rev. 260 (1939). 
hibit the giving of information about prevention of conception and the display or advertisement of contraceptive materials..$^{{ }^{\nu}}$ Most of these states-twenty-six, to be exact-also make it a crime to sell contraceptives. Twenty-one states exempt physicians or druggists. Thirteen make exceptions for medical schools, medical books, or professional journals. In eleven states, licensing statutes, which usually exempt physicians, attempt to regulate the sale and advertising by druggists and supply houses of devices for the prevention of conception or venereal diseases. In only two states-namely, Connecticut and Massachusetts-does the law as written and construed prevent the distribution-and in Connecticut even the use-of contraceptives, regardless of medical necessity. Yet, in all of these states, contraceptives are readily available in the drugstores, although Massachusetts and Connecticut doctors can prescribe a diaphragm, which should be fitted by a physician, only at their peril.

Following the precedent of a federal court that in 1915 construed the unqualified abortion provisions of the Comstock law to exempt the medical profession, ${ }^{46}$ another federal court in 1936 finally decreed a similar exemption of the medical profession from the contraceptive provisions. This decision, United States v. One Package, came after more than fifteen years of unsuccessful efforts, opposed always by representatives of the Roman Catholic Church, to persuade Congress to write such an exception into the law by amendment. It was forecast by an earlier federal court decision in 1930, arising out of a suit between two manufacturers of contraceptives over the infringement of a trademark, in which Judge Thomas W. Swan suggested that the criminal code should apply only where the sender shipped or mailed contraceptives in interstate commerce for "illegal contraception or abortion or for indecent or immoral purposes." ${ }^{\text {48 }}$ The key word in this quotation is "illegal." Davis $v$. United States, ${ }^{50}$ decided three years later, a wholesale druggist successfully contended that "unlawful intent" was essential to a conviction. United States v. One Package, arising out of the importation of contraceptives into the United States by Dr. Hannah M. Stone, squarely held that the contraceptive provisions of the Tariff Act of 1930, similar to those of the original Comstock law, did not apply to a physician. In his opinion, Judge Augustus N. Hand said: $:^{51}$

${ }^{15}$ For this information and the statistical summary of current contraceptive legislation contained in the balance of this paragraph, the writer is indebted to CaLDERoNE, op. cit. supra note 3, app. B, at 196, consisting of a summary, Birth Control Laws in the United States, prepared by Harriet F. Pilpel and Theodora Zavin and first published in Abrakam Stone \& Lena Levine, The Premarital ConsultaTION (1956).

10 Bours v. United States, 229 Fed. 960 (7th Cir. x915).

4786 F.2d 737 (2d Cir. 1936).

${ }^{48}$ Youngs Rubber Corp. v. Lee \& Co., 45 F.2d 103, 109 (2d Cir. 1930).

${ }^{20}$ But see, for a different, although distinguishable, result, Lanteen Laboratories v. Clark, 294 Ill. App. 81,13 N.E.2d 678 (1938).

${ }^{50} 62$ F.2d 473,475 (6th Cir. 1933).

${ }^{51} 86$ F.2d at 737 . 
We are satisfied that this statute, as well as all of the acts we have referred to, embraced only such articles as Congress would have denounced as immoral if it had understood all the conditions under which they were to be used. Its design, in our opinion, was not to prevent the importation, sale, or carriage by mail of things which might intelligently be employed by conscientious and competent physicians for the purpose of saving life or promoting the well being of their patients.

Thus, sixty-three years after the passage of the original Comstock law, a federal court decided that the law, which read as though its provisions were unequivocal and all-inclusive, actually did not mean what it said.

Literature containing contraceptive information has also obtained a somewhat qualified judicial exemption from the federal statutes. In 193x, Judge John $M$. Woolsey, of Ulysses fame, upheld the admissibility through the customs of two books by Dr. Marie Stopes..$^{52}$ Subsequently, federal court cases tempered these decisions, however. In United States $v$. Nicholas, ${ }^{53}$ it was held that a book dealing with contraception mailed from abroad could not be delivered to the addressee, who was not a physician, in the absence of evidence that the addressee would not abuse the information that it contained. But in United States $v$. Himes, ${ }^{54}$ it was decreed that a magazine, Marriage Hygiene, could be delivered to Norman E. Himes, the local editor, as one in whose hands the magazine would be lawful, since he was the most appropriate distributor of the magazine to physicians and scientists, despite the possibility that he might subsequently misuse the privilege. Ironically, the Roman Catholic best-selling handbook, The Rhythm, has passed through the mails with impunity since its publication in 1932.65

United States $v$. One Package and the peripheral cases referred to above made a significant contribution to the progress of birth control in the United States. Before these decisions, physicians, even in states that had no laws against contraception, could not lawfully obtain contraceptive supplies and information. The mails and common carriers engaged in interstate commerce were closed to them. Publishers had no incentive to print textbooks and articles on the subject. Research was impeded. After these decisions, the door opened to a nationwide advance in the establishment of clinics, to widespread publicity about birth control, and to the active support of the medical profession.

Among the states, barriers to the dissemination of contraceptive information persisted in the face of concerted efforts by the birth-control movement to modify them. ${ }^{56}$ The seemingly unequivocal provisions of the federal statutes before United

\footnotetext{
"2 United States v. One Obscene Book Entitled "Married Love," 48 F.2d 821 (D.C. Cir. I93r); United States v. One Book Entitled "Contraception," 5r F.2d 524 (D.C. Cir. r93 I).

${ }^{53} 97$ F.2d 5 I0 (2d Cir. 1938).

sibid.

${ }^{55}$ See the testimony of Margaret Sanger in Hearings Before Subcommittee No. 8 of the House Committee on the Post Office and Post Roads, on Offenses Against the Postal Service, 74th Cong., Ist Sess. 45,47 (1935).

${ }^{50}$ Stone \& Pilpel, The Social and Legal Status of Contraception, 22 N.C. L. Rev, 212, 220 (1944), where it is stated that only one of the Comstock laws has ever been changed. Compare PA. Stat. ANN. tit. $18, \S \S 777,778$ (1930), with PA. Stat. ANs. tit. 18, $\$ 4524$ (1945).
} 
States v. One Package gave aid and comfort to the opposition. New York became an early exception, in that its statute permitted the prescription of contraceptives for the cure or prevention of "disease," a word that the Court of Appeals broadly construed in $19 \mathrm{r} 8$ to mean "an alteration of the state of the body ... causing or threatening pain or sickness." ${ }^{\text {"57 }}$ With the decision in United States v. One Package, however, it was expected that the two holdout states, Massachusetts and Connecticut, would quickly follow suit ${ }^{58}$ Not so. The supreme courts of both states declined to read any exceptions into the law, using, among other reasons, the many unsuccessful attempts to secure an amendment of the law as confirmation of a legislative intent to make no exceptions. ${ }^{59}$ Two of these cases, Commonwealth v. Gardner (Massachusetts) $^{60}$ and Tileston v. Ullman (Connecticut), ${ }^{61}$ reached the United States Supreme Court, only to be dismissed on jurisdictional grounds. No constitutional question as to deprivation of life, liberty or property under the fourteenth amendment arose, the Court held, in Tileston v. Ullman, where a doctor brought suit on behalf of his patients, thereby implying that such a question could be presented in a suit brought by the patients themselves.

The paradox inherent in these decisions is pointed up by two other Massachusetts cases. Commonwealth v. Corbett ${ }^{62}$ and Commonwealth v. Werlinsky ${ }^{63}$ held it to be the law of Massachusetts that the seller of an article that is capable of use either for the prevention of conception or for the prevention of the spread of venereal disease could not be convicted without proof that he sold the article with the intent that it be used to prevent conception. ${ }^{64}$ The constitutionality of legislation against contraceptives depends upon a proper exercise of the police power on behalf of health, safety, welfare, and morals. ${ }^{65}$ Assuming that such legislation is a proper exercise of this power, as the highest courts of Massachusetts and Connecticut have, indeed, concluded, then it would seem inconsistent to permit the sale of contraceptives for the prevention of venereal disease, presumably in an illicit relationship

${ }^{67}$ People v. Sanger, 222 N.Y. I92, 118 N.E. 637 (1918).

${ }^{88}$ Stone \& Pilpel, The Social and Legal Status of Contraception, 22 N. C. L. Rev. 212, 223 (1944).

${ }^{80}$ Commonwealth v. Allison, 227 Mass. 57, I16 N.E. 265 (1917); Commonwealth v. Gardner, 300 Mass. 372, 15 N.E.2d 222, 305 U.S. 559 (1938); State v. Nelson, 126 Conn. 412, II A.2d 856 (1940); Tileston v. Ullman, 129 Conn. 84,26 A.2d 582, 318 U.S. 44 (1942).

${ }^{10} 305$ U.S. 559 (1938).

01318 U.S. 44 (1943).

${ }^{62} 307$ Mass. 7, 29 N.E.2d 15 I (1940).

03 307 Mass. 608, 29 N.E.2d I50 (I940).

${ }^{01}$ But see State v. Tracy, 29 N.J. Super. I45, ro2 A.2d 52 (App. Div. 1953), cert. denied, 15 N.J. 79, 104 A.2d 94 (1954), where under a statute making it a crime to sell contraceptives "without just cause," the defendant-owner of prophylactic vending machines was convicted of disorderly conduct, unlawful intent not being required. Convictions of two defendants engaged in the wholesale rubber business for possessing and selling contraceptives were sustained under this same statute in State v. Kohn, 42 N.J. Super. 578, I27 A.2d 451 (Essex County Ct. 1956). This statute was finally declarèd unconstitutional in State v. Kinney Building Drug Stores, Ine., 56 N.J. Super. 37, I5I A.2d 430 (Essex County Ct. I959). For the application of the Wisconsin statute to the possessor of a contraceptive vending machine, see State v. Arnold, 217 Wis. 340,258 N.W. 843 (1935).

${ }^{\circ 0}$ Commonwealth v. Allison, 227 Mass. 57, 62, 116 N.E. 265, 266 (1917). 
between two unmarried persons, and at the same time prohibit their sale for use by married persons to prevent pregnancy upon health grounds.

Five Connecticut actions currently in litigation have framed their issues with a view to plugging the jurisdictional loophole in Tileston v. Ullman. One action, brought by an eminent New Haven gynecologist, C. Lee Buxton, M.D., alleges that he can not, without risk of criminal prosecution and loss of his license to practice medicine, prescribe contraceptives for a twenty-five-year-old married woman patient with hypertensive cardiovascular disease and other serious physical conditions resulting from a cerebral hemorrhage during an earlier pregnancy that terminated in a stillbirth. ${ }^{86}$ This patient, for whom even the use of a contraceptive, if prescribed by her physician, will be a criminal offense, has also brought suit on her own behalf. ${ }^{67}$ Other cases present differing problems of necessity-an Rh positive-Rh negative blood factor that has already produced four consecutive births of a foetus dead at the time of delivery or within forty-eight hours thereafter ${ }^{08}$ a baffling genetic problem causing the death of three congenitally abnormal children within nine, six, and ten days, respectively, after birth, with the probability of psychological stress on the mother to the breaking point in the event of another pregnancy; ${ }^{60}$ and lastly, a case of economic hardship to a young couple who have not yet completed their studies. $^{70}$ Appeals taken from the expectedly adverse decisions in the Connecticut courts $^{71}$ are now pending before the Supreme Court of the United States.

Three additional Connecticut actions brought by Protestant clergymen, to whom marriage counselling is an essential part of their pastoral responsibilities, allege that the Connecticut law infringes their religious freedom under the first amendment to the United States Constitution. ${ }^{72}$

As a practical matter, no demonstrable relationship exists in Massachusetts and Connecticut between restrictive legislation against contraception and the birth rate. In 1954, the birth rate in Massachusetts was the third lowest in the nation; in Connecticut, the fifth lowest. ${ }^{73}$ If such legislation were not more honored in the breach than in the observance, the reverse should be true. ${ }^{74}$

While it was a predominantly Protestant legislative body that put contraceptives into the Comstock laws, Roman Catholic pressure has been responsible for keeping them there. Almost the only opposition to amendment of the laws to exempt the

${ }^{\circ 0}$ Buxton v. Ullman, 147 Conn. 48, I56 A.2d 508 (1959).

${ }^{07}$ Doe v Ullman, ibid.

${ }^{88}$ Hoe v. Ullman, ibid.

${ }^{a 9}$ Poe v. Ullman, ibid.

${ }^{70}$ Roe v. Ullman, No. 87984, New Haven County Ct., withdrawn and Trubek v. Ullman, No. 90417, New Haven County Super. Ct., substituted therefor.

${ }^{71}$ Buxton v. Ullman, 147 Conn. 48 , 156 A.2d 508 (1959).

72 Willard v. Ullman, No. 90317; Livingston v. Uliman, No. 90316; Teague v. Ullman, No. 90315all of which are pending in the Superior Court for New Haven County.

${ }^{73}$ Information Please almanac 267 (1957).

7t One of the justifying reasons for this particular use of the police power could be "to promote a maintenance and increase of population," said the Connecticut Supreme Court of Errors in State v. Nelson, I26 Conn. 412, 425, II A.2d 856, 862 (1940). 
medical profession has come from representatives of the Roman Catholic Church, which believes that so-called artificial contraception is contrary to natural law and intrinsically evil. Pressure from Roman Catholic groups, both lay and clerical, has been sufficiently intense in a state like Connecticut to prevent passage of amending legislation in the Roman Catholic-dominated Senate, although on six different occasions between 1943 and I957, amendments were passed by the House. Roman Catholic opposition in Massachusetts succeeded in defeating similar amendments in two state-wide referenda on the subject in 1942 and 1946 . At the same time, it may be noted, Roman Catholic opponents of contraception have no scruples about promoting the distribution of literature on their own approved safe-period or rhythm method, which accomplishes the same result, if it works, without "artificial" contraceptives.

Despite the exemption of physicians from restrictive laws against contraceptives everywhere except in Connecticut and Massachusetts, birth control still remains a hotly-contested issue in other areas of human life presenting situations more complex than the doctor-patient relationship. People of means; it is generally agreed, are not irrevocably prejudiced, although they are doubtless inconvenienced, by the kind of legislation still prevailing in Connecticut and Massachusetts. If a woman is confronted with a refusal by her physician to give contraceptive advice in those states, the situation alleged in the pending Connecticut cases, she can go to a doctor or clinic in an adjoining state. The problem is perhaps more serious in the case of persons who for financial or other reasons do not have this degree of mobility, particularly if they look to publicly-financed hospitals or clinics or other welfare services for contraceptive advice. In New York City, for example, until as recently as September $195^{8}$, this ban against contraceptive service in the municipal hospitals was absolute, even in the absence of restrictive legislation. ${ }^{75}$

The resulting controversy that exploded in New York City in the summer of I958 over the right to obtain contraceptive advice from a municipally-operated hospital provides a dramatic illustration of how current political-social views about birth control are more important than the dead hand of the law in determining the availability of information. In New York, it will be recalled, contraceptive advice is expressly authorized by statute for the cure or prevention of disease. ${ }^{76}$ Moreover, the American Medical Association ${ }^{77}$ and the New York Academy of Medicine ${ }^{78}$

${ }^{76}$ Planned Parenthood Federation of America, The Anatomy of a Victory 3-4 (r959). When Dr. Alan Guttmacher came to New York City from Baltimore in 1953 , he talked to the then Hospitals Commissioner, a liberal-minded doctor who had been chairman of a Planned Parenthood Medical Committee in another city. "You can't fight the Archdiocese," the Hospitals Commissioner said. The Health Commissioner gave Dr. Guttmacher a similar reply. In 195I, Dr. Louis M. Hellman discussed the subject with the Chief of Obstetrics and Gynecology at the Bellevue Hospital in New York City. The Chief of Obstetrics and Gynecology had tried to initiate a contraceptive service there, but found that the ban could not be lifted. Id. at 5 .

${ }^{70}$ See People v. Sanger, 222 N.Y. 192, 118 N.E. 637 (1918).

${ }^{77}$ On June 8, 1937. See Birth Control Rev., June r937, p. I.

${ }^{78}$ On March 26, x946, See Planned Parenthood Federation of America, op. cit. silpra note 75 , app. I, at I, 3. The New York Academy of Medicine also went on record in 1930 to the effect that contraception was part of public health medicine. 
have long recognized contraceptive procedures as a legitimate part of medical prac. tice. Yet, due to pressure from and out of deference to the views of the Roman Catholic Church, public officials in New York and elsewhere are reluctant to spend money for a medical service that is sure to provoke religious controversy and criticism. ${ }^{79}$ On the other hand, private citizens may justifiably object, and do, to the curtailment of a proper medical service by a publicly-financed agency merely because of religious pressure reflecting the views of only one, and that a minority, group of citizens.

Thus, it happened on April II, I958, that Dr. Morris A. Jacobs, New York Commissioner of Hospitals, being under pressure from just such a group of nonRoman Catholic private citizens to disclose the Board of Hospitals' birth-control policy, declared in a letter that "there shall be no interference in proper and accepted therapeutic practices nor ethical relationships between patient and physician," a statement that implied a favorable policy on the part of the Board in regard to contraceptive advice. $^{80}$ Three months later, on July 16, 1958, Dr. Jacobs ordered Dr. Louis M. Hellman, Director of Obstetrics at Kings County Hospital, not to fit a contraceptive device to a Protestant diabetic patient, two of whose three children had been delivered by Caesarian section. For nearly two months, while protests bombarded the Board from Protestant groups, Jewish groups, medical societies, Planned Parenthood organizations, and private citizens, the debate continued. Finally, on September 17 , 1958, the full Board reversed Dr. Jacob's order. Yet, this decision did not entirely settle the problem, for the Commissioner's new regulations, later described as a "face-saving device" by Dr. Hellman, ${ }^{81}$ require certification by two physicians, consultation with the woman's husband or spiritual adviser, and consent in writing, restrictions more onerous than would prevail in private practice and comparable to the procedure followed in the case of therapeutic abortions.

Pared down to its essentials, the issue in the New York hospital controversy had serious implications for the medical profession as a whole, and more particularly for doctors who happen to be members of the Roman Catholic faith. A doctor has a legal duty to use reasonable care in the practice of his profession and the treatment of his patients. Reasonable care means treatment in accordance with the professional standards prevailing in his immediate community. In the case of a patient

\footnotetext{
${ }^{79}$ For the Roman Catholic attitude on the use of public funds for contraceptive services or clinics, see the second article by Joseph Kahn in the N.Y. Post on this subject, reprinted in PiANNED PArENTHOOD Federstion of AMErica, $O p$, cit. supra note 75, at 75. Kahn quotes Father Timothy J. Flynn, speaking for the Roman' Catholic Archdiocese of New York, as saying, "If such clinics were established by the city or state, naturally we would be displeased." The ban in New York City went so far as to prevent even discussion of the subject in the fifty settlement houses located in the City Housing Authority projects throughout the five boroughs but supported by private funds. Warren Moscow, Executive Director of the Housing Authority, when asked to explain the ban, replied: "The subject is too controversial."

${ }^{80} \mathrm{~A}$ detailed history of this controversy is given in Pzanned Parenthood Federation of America, op. cit. supra note 75 , app. I.

${ }^{81}$ See Planned Parenthood Federation of America, op. cit. stipra note 75, at 39. Dr. Hellman has indicated that these restrictions did not prevent the immediate effective establishment of contraceptive services. His view is confirmed by Dr. Mary S. Calderone. Ibid.
} 
for whom pregnancy would probably result in death or impairment of health, it is difficult to see how a doctor can avoid the prescription of a contraceptive device, except at the risk of liability for malpractice. Yet, even after the ban in New York was removed, the Archdiocese of New York and the Diocese of Brooklyn in a joint statement pulled the rug out from under their own Roman Catholic physicians by ordering Roman Catholic hospital personnel "not to cooperate with such procedure." 82

The use of public funds to support Roman Catholic-operated hospitals in which contraceptive and other medically-recommended procedures for therapeutic abortion or sterility tests are prohibited has touched off suits in Kentucky, Maryland, and Louisiana to test the legality of such expenditures. ${ }^{83}$ The complaints in these still pending actions allege, inter alia, that the requirements of the Catholic Hospital Code of Ethics ${ }^{84}$ are binding on all Roman Catholic doctors, nurses, and other hospital personnel. It is further charged that adherence to this Code and delegation of complete control of the hospital administration to religious orders of the Roman Catholic Church with their crucifixes, statutes, artifacts, and their ecclesiastical garb are incompatible with the maintenance of a public hospital.

Publicly-financed welfare services no less than hospitals are likewise sensitive to a combination of religious and political pressures to outlaw contraceptive services. Although for more than twenty years, seven southern states, ${ }^{85}$ where the need is acute, have included contraceptive advice within their public health programs, and many public welfare workers elsewhere refer cases to Planned Parenthood clinics, there is little uniformity in these practices. In some instances, official written policy sanctions such referrals. In more instances, the policy has not been dignified by a written regulation and occasionally referrals are sub rosa, not being entered on the client's case history card. ${ }^{86}$ In Pennsylvania, on December 7 , 1958 , the Public Welfare Secretary, Harry Shapiro, refused to implement a resolution of the State Board of Assistance initiated by Emory Bacon, Educational Director of the United Steel Workers Union of America. The resolution, labeled by Roman Catholic Bishop George L. Leech, of Harrisburg, as "brazen" and "arrogant," substance that where a caseworker has reason to believe or has been informed by a client that there is need for maternal health advice or therapy, and where there are no religious restrictions on the part of either worker or client, proper referral may be

sa Planned Parenthood News, Fall 1958 , p. 3. Prior to the removal of the ban, the Roman Catholic Archdiocese of New York said, "It would be extremely unfortunate if our hospitals and medical facilities aimed for the preservation of life should be perverted to seek for the prevention of life."

${ }^{83}$ Abernethy v. City of Irvine, No. 743, Estill County (Ky.) Cir. Ct.; Archer v. County Council, Equity No. 22784, Montgomery County (Md.) Cir. Ct.; Lovell v. Board of Commissioners, Civil No. 8254, E.D. La. All of these suits were brought on behalf of Protestants and Other Americans United for Separation of Church and State and are currently pending.

8t Stipra note $2 \mathrm{I}$.

${ }^{86}$ Virginia, Alabama, North Carolina, South Carolina, Florida, Georgia, and Mississippi.

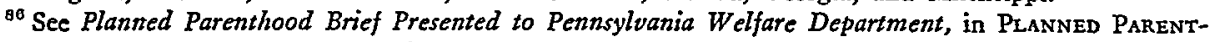
hood Federation of AMERICA, op. cit. supra note 75, app. II.

${ }^{87}$ Pittsburgh Post Gazette, Dec. 19, 1958. 
made to either the client's doctor or a maternal health center. ${ }^{88}$ Previously, the policy of the Board prohibited such referral, except upon request by the client. A similar situation has arisen in Minnesota. ${ }^{80}$ Both controversies culminated in the classic kind of pussyfooting that typifies the reaction of public officeholders to this problem. Caseworkers are not permitted to suggest contraception on their own initiative, no matter how glaring the need. If the relief client brings up the subject, the caseworker may not furnish any information, but may refer the client to her own physician or spiritual adviser.

The lengths to which the Roman Catholic Church, as the principal opponent of contraception, will go to enforce its views pose a continuing threat to personal freedom in this area of human life. The Roman Catholic Church believes that it has a duty to intervene in the secular affairs of the state or of its non-Roman Catholic citizens whenever the spiritual welfare of its own members is concerned. This is the doctrine of the indirect power, the historic formulation of which was expressed by St. Robert Bellarmino in his great sixteenth century polemic, De Summo Pontifice.90 Today, the doctrine is implemented for the most part not by the Pope, but by the activities of lay Roman Catholic groups. Thus, over a period of years, we find a long record of Roman Catholic action, above and beyond verbal persuasion or vilification at legislative hearings or during state-wide referenda, aimed at the enforcement of Roman Catholic views on birth control. Roman Catholic complaints, for instance, have forced the closing of birth-control clinics by the police. ${ }^{11}$ Roman Catholic hospitals have dismissed or compelled the resignation from their staffs of Protestant doctors affiliated in any way with the Planned Parenthood Federation. ${ }^{\text {2 }}$ Roman Catholic charitable organizations have obtained the exclusion of Planned Parenthood organizations from community funds and welfare councils by threatening to withdraw or, in fact, withdrawing-a step in New York City that reduced the income of the Welfare and Health Council so drastically that three years later the chairman remarked that its program was going to hell..$^{33}$

The political implications of these different Roman Catholic pressures, formidable though they may be, are limited and primarily local as compared with the national and international shockwaves resulting from the recent suggestion that American foreign aid programs should include birth control. Action along this line was recommended in July 1959 by President Eisenhower's Committee to Study the

${ }^{88}$ Catholic Transcript (Hartford, Conn.), Jan. I, r959.

${ }^{89}$ In December $195^{8}$, the Ramsey County Welfare Board issued a directive ordering its employees not to give out information on birth control or planned parenthood, even if the welfare client asked for it. Minneapolis Tribune, Jan. 23, 1959; Minneapolis Dispatch, Jan. 23, 1959; Minneapolis Star, Feb. 25, 1959; St. Paul Pioneer Press, Feb. 25, 1959.

20 i Roberto Bellaraino, Opera Omita 243 (i721).

${ }^{21}$ Clinics in Brownsville, New York City, Oct. I916; Waterbury, Conn., June 12, 1939; Salem, Mass., June 3, 1937; Brookline, Mass., Aug. 2, 1937; and Boston', Mass., Aug. 4, 1937.

${ }^{22} \mathrm{~A}$ recent illustration is the dismissal of Dr. Crawford J. Campbell, an orthopedic surgeon, from the staff of St. Peter's Hospital, in Albany, N.Y. N.Y. Times, Dec. 20, 1959, p. 39, col. 4. See Sulloway, op. cit. stipra note 35 , at 48 for additional episodes.

${ }^{03}$ N.Y. Times, Feb. 7, 1956, p. 1, col. 8; see Sulloway, op. cit. supra note 35, at 48-49. 
United States Military Assistance Program, ${ }^{94}$ under the chairmanship of General William H. Draper, Jr., investment banker and former Undersecretary of the Army, and by a background study prepared for the Senate Foreign Relations Committee. ${ }^{95}$ General Draper's Committee concluded that

development efforts in many areas of the world are being offset by increasingly rapid population growth ... that the increase in food production in most of the underdeveloped countries has been falling behind the increase in population.

It foresaw that

unless the relationship between the present trends of population growth and food production is reversed, the already difficult task of economic development will become a practical impossibility.

The Committee recommended that the United States

(r) assist those countries with which it is cooperating in economic aid programs, on request, in the formulation of their plans designed to deal with the problem of rapid population growth, (2) increase its assistance to local programs relating to maternal and child welfare ... and (3) strongly support studies and appropriate research ... to meet the serious challenge posed by rapidly expanding populations. ...

The Stanford report, reaching similar conclusions, noted that "there is nothing to suggest complacency in the face of the world's threatening population and production problems," that "population control will become imperative."96

The Roman Catholic Church, we are advised, will not countenance any solution to the problem of overpopulation that contemplates the use of contraceptive techniques. In a widely-publicized statement dated November 26 , $1959{ }^{97}$ the Roman Catholic Bishops constituting the Administrative Board of the National Catholic Welfare Conference attacked what it called the "campaign of propaganda" in favor of birth-preventive programs. The "population explosion" is belittled as a "terror technique phrase" and a "smoke screen." Artificial birth prevention, they say, is "a morally, humanly, psychologically and politically disastrous approach to the population problem."

Other Roman Catholic bishops speaking separately affirmed this position. Bishop Robert J. Dwyer, of Reno, Nevada, hit out at the "diabolical cleverness" of the population-explosion "propaganda" set forth by "enemies of Christian morality." "There is no shred of evidence," he said, to show that problems of overpopulation can not be controlled by "normal, intelligent, Christian means." "The Bishop of Buffalo, Joseph A. Burke, accused "pseudo-scientists" of "trying to frighten human-

os See President's Comm. to Study the United States Military Assistance Program, Thind Interim Report, Economic Assistance Programs and Administration 42-45 (x959), $\$ 5$ of which is reprinted in 15 Population BulL. I42-44 (1959).

${ }^{95} \mathrm{Ch} .3$ of which is reprinted in 15 Population Bull. I45 et seq (1959).

${ }^{\circ}$ As quoted in Planned Parenthood News, Fall 1959, p. I.

${ }^{27}$ N.Y. Times, Nov. 26, 1959, p. 43, col. I.

-8 Tablet (Brooklyn), Nov. 2I, r959, p. 8, col. x. 
ity" by playing up the threat of overpopulation. God will "not punish those who follow His command to be fruitful, multiply and fill the earth." Eventually, he asserted, the advocates of population control, whom he described as "worshipers at the shrine of Moloch," will one day be forced to "eat humble crow." an impressive array of evidence, suggests that if Bishop Burke's position prevails, the inhabitants of the earth will be fortunate to find anything as nourishing as humble crow left to eat.

American holders of public office, interrogated by the press on the subject of birth control and foreign aid, following the statement of the American bishops, immediately reverted to a posture of defense. Although no one had suggested that the United States was already spending money for birth control as part of its foreign-aid programs, Alonzo Smith, Press Officer of the International Cooperation Administration, volunteered a denial. "Not one penny of foreign aid funds ever .has been used for dissemination of birth control information and there are no plans to.do so." 100 The possibly unanticipated result of this denial was to prompt many Americans to ask "Why not?" Similarly, although no responsible person has suggested that the United States should "impose" contraception on other countries, such candidates for president in 1960 as Governor Edmund G. Brown, ${ }^{101}$ of California, a $\therefore$ Roman Catholic, Senator Hubert H. Humphrey, ${ }^{102}$ of Minnesota, and Adlai E. - Stevenson, ${ }^{103}$ squirmed off the hot seat proclaiming their undying opposition to any such nonexistent policy. Both Senator Humphrey and Adlai Stevenson qualified - their statements with the declaration that the United States should not deny birth$\therefore$ control information and assistance if a nation determines that these are essential 'to' its national welfare. Governor Brown later qualified his statement by saying - that he would oppose banning aid to countries that choose to embark on a. birth. control program, just as he would oppose offering aid on the condition that it be - so used. ${ }^{104}$ As the foremost target for press interrogation on this point, Senator -John F. Kennedy, ${ }^{105}$ of Massachusetts, a Roman Catholic, took the position, backed by Roman Catholic Mayor Wagner, ${ }^{106}$ of New York City, that it would be a "mistake" for the United States to "advocate" birth control in foreign countries, a view endorsed in substance by Eleanor Roosevelt ${ }^{107}$ and President Eisenhower ${ }^{108}$ himself, who said "I can not imagine anything more emphatically a subject that is not a proper political or governmental activity or function or responsibility." Of the

${ }^{99}$ N.Y. Times, July 17, 1958, p. 54, col. I; N.Y. Herald Tribune, July 17, 1958, p. 15, col. 4.

${ }^{100}$ N.Y. Times, Nov. 29,1959, p. I, col. $x$, and p. 43 , col. 4 .

${ }^{101}$ Id., Nov. 29, 1959, p. 43, col. 3; N.Y. Herald Tribune, Nov. 30, 1959, p. 1, col. 4.

${ }^{102}$ N.Y. Herald Tribune, Nov. 30, 1959, p. 2, col. 2; N.Y. Times, Nov. 29, 1959, p. 43, col. 3; id., Dec. 3, 1959, p. 20, col. 5

${ }^{203}$ N.Y. Herald Tribune, Nov. 30, 1959, p. 2, col. 2; N.Y. Times, Nov. 29, r959, p. 43, col. 4, and Dec. 3, 1959, p. 20, col. 4 .

${ }_{104}$ N.Y. Times, Dec. I, 1959, p. .4 , col. 5.

${ }^{105}$ Id., Nov. 28 , I959, p. I, col. 8, and p. I2, col. 2.

${ }^{108}$ N.Y. Times, Dec. I, 1959, p. I, col. 5; N.Y. Herald Tribune, Dec. I, 1959, p. 2, col. 5.

${ }^{107}$ N.Y. Post, Dec. I, 1959; Catholic News (New York), Dec. 12, 1959.

${ }^{108}$ N.Y. Times, Dec. 3, I959, p. I, col. 6, and p. 18, cols. I, 2. 
leading political figures interviewed at this time, only Senator Stuart Symington, ${ }^{109}$ of Missouri, and Governor Nelson Rockefeller, ${ }^{110}$ of New York, took positive positions favoring the furnishing of contraceptive information abroad as a matter of cooperation where requested by other countries. On the other hand, former President Harry S. Truman, who presumably is no longer influenced by political ambitions, opposed the use of federal funds for artificial birth control in underdeveloped countries, but on grounds that certainly, if valid, simplify the whole problem. Referring to the so-called population explosion, he said "I don't believe in that hooey."111

The controversy quickly spread from birth control as part of the United States foreign-aid program to the freedom of a Roman Catholic president to make decisions about such a program. The Right Reverend James A. Pike, Protestant Episcopal Bishop of California, himself an erstwhile eminent member of the bar, questioned whether the opposition of the Roman Catholic hierarchy to birth control in foreign-aid programs "is to be regarded as binding upon the consciences and decision-making of members of their church in high public office."112 Senator John F. Kennedy represented one school of American Roman Catholic thought when he said that if elected president, he would make his own "personal judgment" as to "what would be in the interest of the the United States."113 This point of view has considerable apparent support among distinguished American Roman Catholic spokesmen, including the Reverend John Courtney Murray, S.J., who often gives the impression that American Roman Catholics, unlike Roman Catholics in Europe, enjoy a kind of democratic latitude in which they are free to make their own decisions without obligation to or control by Rome. ${ }^{114}$ The only sanction for such a doctrine, and this is a doubtful one, stems from the failure of the Vatican to repudiate it.

The other school of Roman Catholic thought takes a more restrictive view of a president's duties. ${ }^{115}$ The Reverend John R. Connery, writing in the December I2, 1959, issue of America, ${ }^{116}$ said it would be wrong for a Roman Catholic president to initiate a birth-control program. The problem, Father Connery conceded, is more difficult if he is called upon to cooperate in a program sponsored by others. For

${ }^{100}$ Id., Nov. 29, 1959, p. 43, col. 3, and Dec. 3, 1959, p. 20, col. 4.

${ }_{110}$ N.Y. Herald Tribune, Dec. 1, 1959, p. 2, col. 5; N.Y. Times, Dec. 3, 1959, p. 20, col. 4.

${ }^{211}$ Catholic Transcript (Hartford, Conn.), Dec. 3, 1959.

${ }^{110}$ N.Y. World Telegram, Nov. 28, 1959.

${ }^{113}$ N.Y. Times, Nov, 28,1959 , p. $x$, col. 8.

${ }^{114}$ See the statement of Father John Courtney Murray quoted in Pike, Should A Catholic Be President, Life, Dec. 2x, 1959, p. 78, and a 1948 statement of the American Roman Catholic bishops, also quoted therein, in favor of "our original American tradition of free cooperation between government and religious bodies-cooperation involving no special privilege to any group and no restriction on the religious liberty of any citizen." Id. at 83 .

${ }_{115}$ See for the official view, quoting Pius IX's Syllabus of Errors (I864), condemning the separation of church and state; Pius XII's statement in 1953 that "what is not in accord with the truth [i.e., Roman Catholicism] has objectively no right to existence, propagation or action," id. at 80,83 ; and the Very Reverend Francis J. Connell's statement that the state has the right of repression "when error is doing harm to the spiritual interests of Catholic citizens." Id. at 80 .

${ }^{110}$ Connery, May A Catholic President Sign, I02 AMERICA 353 (1959). 
example, he said, any conscientious man, not merely a Roman Catholic, could be confronted with a religious problem in signing a foreign-aid bill containing a birthcontrol provision. It would "clearly be wrong" for a Roman Catholic president to approve the program, and signing the bill is regarded as tantamount to approval. One solution, Father Connery suggests, might be for a Roman Catholic president to decline to sign the bill without vetoing it, in which event it would become law in ten days without his signature. In the last analysis, as Bishop Pike has written, ${ }^{117}$ the question of whether we should vote for a Roman Catholic for president depends on which Roman Catholic is the candidate.

Quite apart from the attitude of a Roman Catholic president toward birth control, it seems likely that for other reasons, the limitation of population growth will continue to be a controversial subject in years to come. Already, American holders of public office are beginning to find themselves faced with serious moral, social, and religious issues, all of which, in turn, mean "political" issues, in the fields of foreign aid and public health. Pressure on these office-holders to make contraceptive services available, particularly in foreign-aid programs, may be expected to increase as the skyrocketing populations of underdeveloped countries get closer to the doubling point during the next forty years. Understandably, if the American taxpayer is going to continue to spend billions for foreign aid, he is entitled to know that his dollars are not wasted through a failure to control population growth. Likewise, we may expect a widening recognition of the need for population control as an integral part of our public health programs; and, indeed, on October 21, 1959, the American Association of Public Health made a recommendation to this effect. ${ }^{118}$ The next step would be for the United States Public Health Service to give the problem its official attention and for the National Institutes of Health to finance with public funds what Bishop Pike has called a "crash program" to improve the efficiency and reduce the expense of contraceptive techniques, including the Roman Catholicapproved rhythm. ${ }^{119}$

It should be evident from the history of the legal and political aspects of birth control in the United States that progress is made slowly in dealing with these controversial subjects. Existing laws do not prevent the inclusion of birth control in our foreign-aid commitments, in our national health programs, or in publiclyfinanced research, but the first steps in any of these directions will still be fraught with political hazard to the public servants who advocate them. There is, in addition, the opposition of the Roman Catholic Church; but even Roman Catholic opposition is hardly sufficient to explain or justify the timorousness that characterizes the attitude of officeholders and others who are in a position to provide leadership and money for future work in this field. It would be naive, if not irresponsible, to attribute the previously cited views of such statesmanlike and courageous persons as

\footnotetext{
${ }^{127}$ Pike, supra note Ir4.

${ }^{118}$ Policy Statement on the Population Problem, 15 Population Bull. 158 (1959).

${ }_{119}$ N.Y. Times, Jan. 15, 1960, p. 7, col. I.
} 
President Eisenhower and Eleanor Roosevelt to fear of the Roman Catholic Church. On the other hand, respect for the Roman Catholic Church and concern over how people in general will react to such massive ecclesiastical resistance are a source of enough apprehension in many minds to paralyze constructive effort in the area of: population control. On this point, fortunately, the indications are that apprehension will yield and is already yielding through education and understanding to the more positive view that society possesses in birth-control techniques, contrary to the racesuicide predictions of Roman Catholic spokesmen in the I920's, one of the more constructive and perhaps essential means of human survival. 